\title{
EFFECT OF AMIDATED ALGINATE ON CHOLESTEROL IN SERUM, LIVER AND FAECES OF RATS FED FAT AND CHOLESTEROL-CONTAINING DIET
}

\author{
M. Marounek ${ }^{1}$,Z. Volek ${ }^{1}$, T. Taubner ${ }^{1}$, D. Duškova ${ }^{1}$, L. Kalachniuk ${ }^{2}$, D. Tsvilikhovskyi ${ }^{2}$ \\ marounek.milan@vuzv.cz, kalachnyuk_liliya@nubip.edu.ua
}

${ }^{1}$ Institute of Animal Science, Přátelství 815, Prague 22, Czech Republic

${ }^{2}$ National University of Life and Environmental Sciences of Ukraine, 15 Heroiv Oborony str., Kyiv 03041, Ukraine

Polysaccharides (of which there is alginic acid) play a key role in the digestion and absorption of nutrients because they can increase the viscosity and form a gel in the intestine. Considering results of our previous studies of the effect of pectin, cellulose and their amidated derivatives on digestion in rats and experimental data of other scientists, we decided to study the effect of amidated alginate on level of cholesterol in the blood serum, liver and feces in the rats which were fed by diet supplemented with fat and cholesterol.

Female rats were fed a control (1) (basal diet without cholesterol and amidated alginate sumplements) and two experimental (2 and 3) diets supplemented with cholesterol $(10 \mathrm{~g} / \mathrm{kg})$ and amidated alginate (0 and $40 \mathrm{~g} / \mathrm{kg}$, respectively). All diets contained palm fat. In rats fed the cholesterol-containing diet, amidated alginate significantly decreased serum total and low density lipoprotein cholesterol, hepatic cholesterol and lipids in the liver tissue. Amidated alginate increased faecal concentration of fat from 61 to $91 \mathrm{mg} / \mathrm{g}$. In the rats fed amidated alginate, the faecal concentrations of cholesterol, bile acids and total sterols were not significantly influenced. It can be concluded that the reduction of cholesterolemia in treated rats was probably based on the removal of fat from the intestine, rather than on interruption of cholesterol circulation in the liver.

Keywords: RATS, FAECES, CHOLESTEROL, FATS, BILE ACIDS, N-ALKYLAMIDATED ALGINATE

\section{ВПЛИВ АМІДОВАНОГО АЛЬГІНАТУ НА ВМІСТ ХОЛЕСТЕРОЛУ В СИРОВАТЦІ КРОВІ, ПЕЧІНЦІ І ФЕКАЛІЯХ ЩУРІВ, УТРИМУВАНИХ НА РАЦІОН З ДОДАВАННЯМ ЖИРУ І ХОЛЕСТЕРОЛУ}

\author{
М. Мароунек ${ }^{1}$, 3. Волєк', Т. Таубнер ${ }^{1}$, Д. Душкова ${ }^{1}$, Л. Калачнюк², Д. Цвіліховський² \\ marounek.milan@vuzv.cz, kalachnyuk_liliya@nubip.edu.ua
}

${ }^{1}$ Інститут тваринництва,

Прателстві 815, Прага 22, Чеська Республіка

${ }^{2}$ Національний університет біоресурсів і природокористування України, вул. Героїв Оборони, 15, м. Київ, 03041, Україна

Полісахариди (серед яких є й альгінова кислота) відіграють однуз ключових ролей у прочесі травлення і всмоктування поживних речовин тому, що вони можуть збільшувати в'язкість й утворювати гель у кишечнику. Враховуючи результати наших попередніх досліджень впливу пектину, иелюлози $і$ їх амідованих похідних на травлення у щурів та експериментальні дані інших вчених, ми вирішили вивчити вилив амідованого альгінату на рівень холестеролу в сироватиі крові, печінки і фекалій у шурів, які харчувалися згідно з раиіоном з добавками жиру і холестеролу.

Самок шурів утримували на ращіонах: контрольному (1), двох експериментальних (2 і 3), до яких додавали холестерол (0, 10 і 10 г/кг відповідно) і амідований альгінат (0, 0 і 40 г/кг відповідно). Усі рачіони містили пальмову олію. У щурів, яких годували згідно з холестерол-вмісною дієтою, амідований альгінат вірогідно знижував рівень холестеролу (як загального, так і ліпопротеїнів низької щільності) у сироватиі крові, холестеролу в печінці та ліпідів у тканинах печінки. Використання амідованого альгінату у раціоні шурів сприяло збільшенню концентращії жиру від 61 до 91 мг/2 у феккаліях тварин, які його споживали. У фекаліях щурів, яким згодовували амідований альгінат, концентрачії холестеролу, жовчних кислот і загальних стеролів не зазнавали вірогідного його впливу. Тому можна зробити висновок 
про те, щзо зниження холестеролемії в щурів, які споживали амідований альгінат, ймовірно, базується швидше на видаленні жиру з кишечнику, ніж на перериванні цุиркулящії холестеролу в печінці.

Ключові слова: ЩУРИ, ФЕКАЛІІ, ХОЛЕСТЕРОЛ, ЖИРИ, ЖОВЧНІ КИСЛОТИ, N-АЛКІЛАМІДОВАНИЙ АЛЬГІНАТ

\title{
ВЛИЯНИЕ АМИДИРОВАННОГО АЛЬГИНАТА НА СОДЕРЖАНИЕ ХОЛЕСТЕРОЛА В СЫВОРОТКЕ КРОВИ, ПЕЧЕНИ И ФЕКАЛИЯХ КРЫС, СОДЕРЖАЩИХСЯ НА РАЦИОНЕ С ДОБАВЛЕНИЕМ ЖИРА И ХОЛЕСТЕРОЛА
}

\author{
М. Мароунекㄴ, 3. Волек ${ }^{1}$, Т. Таубнер ${ }^{1}$, Д. Душкова \\ marounek.milan@vuzv.cz, kalachnyuk_liliya@nubip.edu.ua
}

${ }^{1}$ Институт животноводства, Прательстви 815, Прага 22, Чешская республика

${ }^{2}$ Национальный университет биоресурсов и природопользования Украины, ул. Героев Обороны, 15, г. Киев, 03041, Украина

Полисахариды (среди которых есть и альгиновая кислота) играют одну из ключевых ролей в процессе пищеварения и всасывания питательных веществ потому, что они могут увеличивать вязкость и образовывать гель в кишечнике. Учитывая результаты наших предыдущих исследований влияния пектина, целлюлозы и их амидированных производных на пищеварение у крыс и экспериментальные данные других ученых, мы решили изучить влияние амидированного альгината на уровень холестерола в сыворотке крови, печени и фекалиях у крыс, содержащихся на ращионе с добавками жира и холестерола.

Самки крыс содержались на рационах: контрольном (1), двух экспериментальных (2 и 3), к которым добавляли холестерол (0, 10 и 10 г/кг соответственно) и амидированный альгинат (0, 0 и 40 г/кг, соответственно). Все рачионы содержали пальмовое масло. У крыс, которых кормили согласно холестеролсодержащему ращиону, амидированыий альгинат достоверно снижал уровень холестерола (как общего, так и липопротеинов низкой плотности) в сыворотке крови, холестерола в печени и липидов в тканях печени. Амидированный альгинат увеличивал концентрачии жсира от 61 до 91 мг/2 у фекалиях животных, которые его потребляли. У фекалиях крыс, которым скармливали амидированный альгинат, концентрации холестерола, желчных кислот и общих стеролов не испытывали достоверного его влияния. Поэтому можно сделать вывод о том, что снижение холестеролемии у крыс, потреблявших амидированный альгинат, вероятно, базируется скорее на удалении жира из кишечника, чем на прерывании циркуляции холестерола в печени.

\section{КЛючевЫе слова: КРЫСЫ, ФЕКАЛИИ, ХОЛЕСТЕРОЛ, ЖИРЫ, ЖЕЛЧНЫЕ КИСЛОТЫ, N-АЛКИЛАМИДИРОВАННЫЙ АЛЬГИНАТ}

Alginic acid is a copolymer of $\alpha-1-4$ linked $\beta$-D-mannuronate and $\alpha$-L-guluronate, present in the cell walls of brown algae [1]. Alginate has a wide use across a variety of industries, including food, textile and pharmaceutical. In the food industry, alginate is used as a thickening agent for drinks, ice cream and as a gelling agent for jellies [4]. In the small intestine, gell-forming polysaccharides increase viscosity and affect the process of digestion and absorption of nutrients. In ileostomy subjects, alginate increased fat excretion and decreased excretion of bile acids [10]. In overweight male subjects, alginate reduced the uptake of cholesterol and glucose [3], and has been recommended as a dietary supplement for the maintenance of health and the alleviation of certain cardiovascular diseases [2]. When alginate was present in the diet of rats, the serum total cholesterol and LDL-cholesterol were significantly decreased [14]. Physiological effects of alginate are similar to those of pectin, which is a polymer of D-galacturonate linked by $\alpha-1-4$ bonds and methoxylated to a varying extent at the carboxyl moieties [1]. Pectin reduced plasma and liver concentration of cholesterol in rats [5], hamsters [12], and guinea pigs [3]. Marounek et al. [8] compared effects of citrus pectin 
and octadecylpectinamide in experiments with rats fed a diet containing palm fat and cholesterol. Amidated pectin of lower degree of substitution (30\%) increased serum HDL-cholesterol at expense of other cholesterol fractions. Amidated pectin of higher degree of substitution (53\%) significantly reduced total serum cholesterol without reduction of HDL-cholesterol concentration. Pectin used in this study increased caecum weight, but had no effect on cholesterol homeostasis. These data show convincingly that the change of hydrophilic pectin into its hydrophobic derivative (octadecylpectinamide) greatly increased the hypocholesterolemic activity. Hence, the aim of the present experiment was to examine hypocholesterolemic activity of $\mathrm{N}$-alkylamidated alginate prepared by reaction with octadecylamine.

\section{Materials and methods}

Amidated alginate was prepared from commercially available alginate (Sigma-Aldrich). First, the methylester was prepared via esterification with methanol. Then, the methylester was amino-dealkoxylated with N-octadecylamine. The amino-dealkoxylation procedure has been described previously [11].

Eighteen female Wistar rats were housed individually and fed a basal (control) diet for 4 weeks. Then, the rats were divided into 3 groups of 6 animals each. The experimental diets no. 2 and 3 were supplemented with cholesterol at $10 \mathrm{~g} / \mathrm{kg}$, and amidated alginate at 0 and $40 \mathrm{~g} / \mathrm{kg}$, respectively (table 1). Food and water were available ad libitum.

Table 1

\section{Composition of control} and experimental diets, $\mathrm{g} / \mathrm{kg}$

\begin{tabular}{|l|c|c|c|}
\hline \multirow{2}{*}{\multicolumn{1}{|c|}{ Ingredients }} & \multicolumn{3}{c|}{ Diets } \\
\cline { 2 - 4 } & $\begin{array}{c}1 \\
\text { (control) }\end{array}$ & $\begin{array}{c}2 \\
\text { (cholesterol) }\end{array}$ & $\begin{array}{c}3 \\
\text { (cholesterol } \\
+ \text { alginate) }\end{array}$ \\
\hline Cholesterol & 0 & 10 & 10 \\
\hline Amidated alginate & 0 & 0 & 40 \\
\hline Palm fat $^{\mathrm{a}}$ & 60 & 50 & 50 \\
\hline Cellulose $^{\text {(c) }}$ & 60 & 60 & 20 \\
\hline Rat diet ST-1 ${ }^{\mathrm{b}}$ & 880 & 880 & 880 \\
\hline
\end{tabular}

Note: a - supplied by AarhusKarlshamn Sweden $A B$ (Prague); ${ }^{\mathrm{b}}$ - contained crude protein, fibre, fat and cholesterol at 220, 46, 31 and $0.24 \mathrm{~g} / \mathrm{kg}$, respectively.
Faeces were collected during the last five days of the experiment, weighed, pooled, and stored at $-40{ }^{\circ} \mathrm{C}$ until analysis. At the end of the experiment, the rats received $4 \mathrm{~g}$ of feed before sacrifice. All manipulations with rats were carried out considering prescriptions of European Convention about protection of animals used in experimental and scientific purposes: they were sacrificed via decapitation after anaesthesia via inhalation of isoflurane (Torrex Chiesi CZ, Ltd., Prague). Mixed blood samples were drawn at the time of sacrifice to obtain the serum. After laparotomy, the livers were excised and stored at $-40{ }^{\circ} \mathrm{C}$ until analysis.

The serum levels of total cholesterol, LDL-cholesterol, triacylglycerols, aspartate aminotransferase (AST), and alanine aminotransferase (ALT) were determined using commercial kits (Erba-Lachema, Ltd., Brno, Czech Rep.). The total hepatic and faecal lipids, faecal neutral sterols and bile acids were determined as described previously [13].

Treatment effects were evaluated using a one-way analysis of variance, which was calculated with the Statistica 10 software (StatSoft, Inc., Tulsa, USA). Significant differences $(\mathrm{P}<0.05)$ were identified using Tukey's test.

\section{Results and discussion}

Cholesterol supplementation significantly increased serum, hepatic and faecal cholesterol concentrations, serum LDL-cholesterol, faecal coprostanol, total neutral sterols, bile acids and total sterols (tables 2 and 3). In rats fed the cholesterolcontaining diet amidated alginate significantly decreased serum total and LDL-cholesterol, hepatic cholesterol and total lipids in the hepatic tissue. Amidated alginate significantly increased activity of aminotransferases in serum; however, elevated activities were not significantly different from those of rats fed the basal diet no. 1. In rats fed the cholesterol-containing diet, amidated alginate significantly increased faecal concentration of total neutral sterols, but not concentrations of cholesterol, coprostanol, bile acids and total sterols. Amidated alginate significantly increased concentration of fat in faeces.

It follows from our results that amidated alginate is an efficient hypocholesterolemic 


\section{Effect of amidated alginate on serum parameters, hepatic cholesterol and fat concentrations in the rats, $\mathrm{M} \pm \mathrm{SD}, \mathrm{n}=6$}

\begin{tabular}{|c|c|c|c|}
\hline \multirow{3}{*}{ Parameters } & \multicolumn{3}{|c|}{ Groups of animals } \\
\hline & 1 & $\begin{array}{c}2 \\
\text { (cholesterol) }\end{array}$ & $\begin{array}{c}3 \\
\text { (cholesterol+alginate) }\end{array}$ \\
\hline & control & \multicolumn{2}{|c|}{ experimental } \\
\hline \multicolumn{4}{|c|}{ Serum concentrations or activities } \\
\hline Total cholesterol, $\mu \mathrm{mol} / \mathrm{ml}$ & $2.05 \pm 0.21^{\mathrm{a}}$ & $3.30 \pm 0.82^{b}$ & $1.63 \pm 0.15^{\mathrm{c}}$ \\
\hline LDL-cholesterol, $\mu \mathrm{mol} / \mathrm{ml}$ & $0.42 \pm 0.12^{\mathrm{a}}$ & $1.65 \pm 0.83^{\mathrm{b}}$ & $0.38 \pm 0.15^{\mathrm{a}}$ \\
\hline Triacylglycerols, $\mu \mathrm{mol} / \mathrm{ml}$ & $0.72 \pm 0.17$ & $1.10 \pm 0.71$ & $0.65 \pm 0.26$ \\
\hline AST, nkat $/ \mathrm{ml}$ & $3.07 \pm 0.87^{\mathrm{ab}}$ & $2.75 \pm 0.21^{\mathrm{a}}$ & $3.69 \pm 0.60^{\mathrm{b}}$ \\
\hline ALT, nkat/ml & $0.95 \pm 0.17^{\mathrm{a}}$ & $0.78 \pm 0.13^{\mathrm{a}}$ & $1.19 \pm 0.21^{\mathrm{b}}$ \\
\hline \multicolumn{4}{|c|}{ Hepatic concentrations } \\
\hline Cholesterol, $\mu \mathrm{mol} / \mathrm{g}$ & $6.37 \pm 0.43^{\mathrm{a}}$ & $29.23 \pm 3.72^{\mathrm{b}}$ & $6.26 \pm 0.43^{\mathrm{a}}$ \\
\hline Total lipids, mg/g & $44.2 \pm 4.6^{\mathrm{a}}$ & $77.5 \pm 13.2^{\mathrm{b}}$ & $44.5 \pm 5.7^{\mathrm{a}}$ \\
\hline
\end{tabular}

Note: in this and the next table ${ }^{\mathrm{a}-\mathrm{c}}$ values in the same row with different superscripts differ significantly $(\mathrm{P}<0.05)$.

Table 3

\section{Effect of amidated alginate on faecal concentration of cholesterol, coprostanol, bile acids and fat in the rats, $M \pm S D, n=6$}

\begin{tabular}{|c|c|c|c|}
\hline \multirow{3}{*}{ Parameters } & \multicolumn{3}{|c|}{ Groups of animals } \\
\hline & 1 & $\begin{array}{c}2 \\
\text { (cholesterol) }\end{array}$ & $\begin{array}{c}3 \\
\text { (cholesterol+alginate) }\end{array}$ \\
\hline & control & \multicolumn{2}{|c|}{ experimental } \\
\hline Total cholesterol, $\mu \mathrm{mol} / \mathrm{g}$ & $11.11 \pm 0.30^{\mathrm{a}}$ & $61.46 \pm 6.26^{\mathrm{b}}$ & $66.96 \pm 8.27^{\mathrm{b}}$ \\
\hline Coprostanol, $\mu \mathrm{mol} / \mathrm{g}$ & $3.32 \pm 0.45^{\mathrm{a}}$ & $13.90 \pm 5.43^{b}$ & $20.39 \pm 5.07^{c}$ \\
\hline Total neutral sterols, $\mu \mathrm{mol} / \mathrm{g}$ & $19.45 \pm 0.63^{\mathrm{a}}$ & $84.11 \pm 4.24^{\mathrm{b}}$ & $95.38 \pm 10.42^{\mathrm{c}}$ \\
\hline Bile acids, $\mu \mathrm{mol} / \mathrm{g}$ & $5.99 \pm 0.70^{\mathrm{a}}$ & $13.12 \pm 1.64^{\mathrm{b}}$ & $11.11 \pm 1.05^{\mathrm{b}}$ \\
\hline Total sterols, $\mu \mathrm{mol} / \mathrm{g}$ & $25.44 \pm 0.64^{\mathrm{a}}$ & $97.23 \pm 5.51^{\mathrm{b}}$ & $106.48 \pm 10.49^{b}$ \\
\hline Fat, $\mathrm{mg} / \mathrm{g}$ & $48.18 \pm 25.05^{\mathrm{a}}$ & $61.31 \pm 20.83^{\mathrm{ab}}$ & $90.83 \pm 12.61^{\mathrm{b}}$ \\
\hline
\end{tabular}

agent. Our finding, however, is not consistent with a limited effect of amidated alginate on faecal excretion of cholesterol and bile acids. The hypocholesterolemic effect of amidated alginate thus differs from that of amidated pectin, in spite of the fact that both modified polysaccharides are polymers of uronic acids. The effect of amidated pectin is based on the interruption of enterohepatic circulation of cholesterol [7], whereas the effect of amidated alginate is based on the removal of fat from the intestine via faeces. Saturated fat may have a greater impact on serum cholesterol than the dietary cholesterol [6]. The excretion of bile acids was non-significantly lower in rats fed the diet supplemented with amidated alginate, presumably because of the lower synthesis of bile acids in the liver, in response to lower availability of fat.

\section{Conclusion}

It could be concluded from our results that amidated alginate is an efficient hypocholesterolemic agent. At the same time, it has a limited effect on faecal excretion of cholesterol and bile acids. The effect of amidated alginate is based on the removal of fat from the intestine via faeces. Amidated alginate reduces cholesterolemia in rats. Observed in these studies hypocholesterolemic effect of amidated alginate is rather based on the removal of fat from the intestine than on interruption of the enterohepatic circulation of cholesterol.

Perspectives of further investigation. The last statement needs further research of amidated polysaccharide influence on the digestive processes of animals. 
Acknowledgements. Preliminary results were presented as a poster on the conference Polysaccharides - Glycoscience. The study was supported by Czech research project MZE 0002701404 .

1. Aspinall G. O. Polysaccharides. Oxford, Pergamon Press, 1970, $228 \mathrm{p}$.

2. Brownlee I.A.,AllenA.,Pearson J.P.,Dettmar P.W., Havler M. E., Atherton M. R., Onsoyen E. Alginate as a source of dietary fiber. Crit. Rev. Food Sci. Nutr., 2005, vol. 45, no. 6, pp. 497-510.

3. Fernandez M. L. Distinct mechanisms of plasma LDL lowering by dietary fiber in the guinea pig: specific effects of pectin, guar gum, and psyllium. Lipid Res., 1995, vol. 36, no. 11, pp. 2394-2404.

4. Cook M. T., Tzortzis G., Charalampopoulos D., Khutoryanskiy V. V. Production and evaluation of dry alginate-chitosan microcapsules as an enteric delivery vehicle for probiotic bacteria. Biomacromolecules, 2011, no. 12 (7), pp. 2834-2840.

5. Judd P. A., Truswell A. S. The hypocholesterolaemic effects of pectins in rats. Br. J. Nutr., 1985, vol. 53, no. 3, pp. 409-425.

6. Lichtenstein A. H., Kennedy E., Barrier P., Danford D., Ernst N. D., Grundy S. M., Leveille G. A., Van Horn L., Williams C. L., Booth S. L. Dietary fat consumption and health. Nutr. Rev., 1998, vol. 56, no. 5, Pt. 2, S3-19.

7. Marounek M., Volek Z., Dušková D., Tůma J., Taubner T. Dose-response efficacy and long-term effect of the hypocholesterolemic effect of octadecylpectinamide in rats Carb. Polym., 2013, vol. 97, no. 2, pp. 772-775.
8. Marounek M., Volek Z., Synytsya A., Čopíková J. Effect of pectin and amidated pectin on cholesterol homeostasis and cecal metabolism in rats fed a highcholesterol diet. Physiol. Res., 2007, vol. 56, no. 4, pp. 433-442.

9. Paxman J. R., Richardson J. C., Dettmar P. W., Corfe B. A. Alginate reduces the increased uptake of cholesterol and glucose in overweight male subjects: a pilot study. Nutr. Res., 2008, vol. 28, no. 8 , pp. 501-505.

10. Sandberg A. S., Andersson H., Bosaeus I., Carlsson N. G., Hasselblad K., Härröd M. Alginate, small bowel sterol excretion, and absorption of nutrients in ileostomy subjects. Amer. J. Clin. Nutr., 1994, vol. 60 , no. 5, pp. 751-756.

11. Synytsya A., Čopíková J., Marounek M., Mlčochová P., Sihelníková I., Skoblya S., Havlátová H., Matějka P., Maryška M., Machovič V. N-octadecylpectinamide, a hydrophobic sorbent based on modification of highly methoxylated citrus pectin. Carb. Polym., 2004, vol. 56, no. 2, pp. 169-179.

12. Terpstra A. H. M., Lapre J. A., De Vries H. T., Beynen A. C. Dietary pectin with high-viscosity lowers plasma and liver cholesterol concentration and plasma cholesteryl ester transfer protein-activityin hamsters. J. Nutr., 1998, vol. 128, no. 11, pp. 1944-1949.

13. Tůma J., Volek Z., Synytsya A., Dušková D., Marounek M. Hydrophobically modified celluloses as novel cholesterol-lowering polymers. Bioresources, 2014, vol. 9, pp. 4266-4273.

14. Wang W., Yoshie Y., Suzuki T. Effect of alginate viscosity on digestibility and lipid metabolism in rats. Nippon Suisan Gakk., 2003, vol. 69, no. 1, pp. $72-79$. 